\title{
Forestry Provisioning Ecosystem Services Extraction by Forest Adjacent Communities: Evidence from Chyulu Hills Forest, Makueni County, Kenya
}

\author{
Musyoka Victoria M*, Ndungu Charles K and Kauti Matheaus K \\ Department of Environmental Science and Land Resources Management, South Eastern Kenya University, Kenya
}

Submission: March 06, 2019; Published: March 22, 2019

*Corresponding author: Musyoka Victoria M, Department of Environmental Science and Land Resources Management, South Eastern Kenya University, Kenya

\begin{abstract}
A study was carried out to examine the types of forest provisioning ecosystem services (FPES) extracted from Chyulu Hills Forest by small holder farmers living in the forest adjacent area. Using a Survey Research Design, the study area was stratified into two sites to enable a comparative analysis approach. This was on the basis of ease of access to the forest. Thus, Mang'elete sub-location which lies adjacent the part of the forest with an electric fence and Kiu sub-location on the section of the forest without a fence were chosen. An interview schedule having closed, and open-ended questions was used to gather information on extraction of FPES from the respondents. Results indicated that Chyulu hills forest is important in providing11 types of FPES namely; khat, firewood, charcoal, medicinal plants, poles and posts, timber, game meat, wild fruits, fodder, carving wood and honey. It was established that farmers in both sub-locations extracted FPES with $35.7 \%$ and $64.3 \%$ of the respondents in Mang'elete and Kiu Sub-locations respectively, extracting the services from the forest. A chi-square test of independence was calculated comparing the frequency of forest resource extraction in Kiu and Mang'elete sub-locations. A significant interaction was found ( $\mathrm{X}^{2}(11)$ $=22.17, \mathrm{p}<0.05$ ), indicating that the extraction was significantly influenced by the sub-location of the respondent. More resources were extracted in Kiu sub-location compared to Mang'elete sub-location. Further analysis revealed that only four out of the eleven identified FPES, i.e. extraction of firewood $\left(X^{2}(1)=2.05\right.$, $p$-value $\left.=0.15\right)$, charcoal $\left(X^{2}(1)=3.07, p\right.$-value $\left.=0.08\right)$, poles and posts $\left(X^{2}(1)=1.49\right.$, $p$-value $\left.=0.22\right)$ and hunting for wild animals $\left(X^{2}(1)=3.75\right.$, p-value $\left.=0.05\right)$ were not significantly influenced by the sub-location of the respondent. Food resources extracted from Chyulu Hills Forest were categorized into wild fruits, vegetables, game meat and honey. In Mang'elete, the most extracted food material was vegetables (44.4\%) while in Kiu sub-location honey was leading at $87.5 \%$. The most extracted herbal medicine in Mang'elete was Terminalia brownii (52.4\%) while in Kiu sub location Grewia bicolar topped at 60.9\%. The study established high dependence on FPES in Kiu as compared to In Mang'elete, sub-location. Those on the fenced border in Mang'elete were found to extract fewer resources due to the fence barrier. Forest adjacent communities extract forest resources irrespective of whether legal or illegal. These findings imply that forest dependency is a reality and therefore conservation can be enhanced by creating awareness of forest benefits to the community and training them on sustainable resource use. The study recommends that degree to which forest governance structures recognize the entitlement of forest adjacent communities and the forest users to the forest and forest products to be improved to ensure local communities benefit more from forest resources.
\end{abstract}

Keywords: Forest barrier; Herbal medicine; Fodder and sustainable resource use

\section{Introduction}

Forests provide several products that underpin many rural livelihood strategies [1]. These products are collectively referred to as 'provisioning services', defined as 'services supplying tangible goods, finite though renewable, that can be appropriated by people, quantified and traded' [2]. According to FAO [3], the livelihood of most rural people of developing countries is strongly linked to natural resources like forest. Regionally, forests have immense value, and are essential for economic development, biodiversity conservation and equitable growth in the region [4]. In most of the developing countries, 70 to 80 percent of the population is rural dwellers relying on forest lands and subsistence agriculture for their livelihoods. For instance, in Asia, about 450 million people rely heavily on forest and trees resources for their livelihoods and in Africa more than 60 percent of the population depends on forests for their food and health [5]. In Kenya, forests support most productive and service sectors, particularly agriculture, fisheries, livestock, energy, wildlife, water, tourism, trade and industry that contribute $33 \%$ to $39 \%$ of the country's GDP. They also contribute about $80 \%$ of all energy used in the country [6]. Locally, those people living around the edges of the forests use the forests as a source of firewood, other wood products, medicinal purposes, honey, for hunting, and for livestock grazing. According 
to Calibre Consultants [7] livelihoods of an estimated 300 million people worldwide living close to tropical forests depend on tree or forest products for daily subsistence. Rural households throughout the developing world rely to varying degrees on a range of products and species collected from the surrounding ecosystems [8]. These FPES are used either for direct household consumption or sold in local, regional and national markets and when included into rural livelihood strategies, help reduce peoples' vulnerability to risks [9]. Some of the forest uses are destructive while others are not such as controlled grazing of livestock and firewood collection as long as the dry wood is the one being collected without interfering with the forest normal growth [10]. Although the importance of FPES to millions of rural households is increasingly being acknowledged, destruction of the forest's ecosystem is being witnessed in most parts of the world. For example, in Kenya the Chyulu Hills is a critical dry land water catchment in Southern Kenya but its environmental integrity is increasingly threatened by inappropriate human activities like charcoal burning, logging and livestock incursion [11]. In view of its role in sustaining the socio-economic welfare of many rural and urban populations and provision of water to large populations of wildlife species, it is imperative that its contribution to the livelihoods of smallholder farmers in terms of provision of FPES be understood. As observed by Timko et al. [12] if properly managed, these forest products can serve as incentive for forest communities to protect the forest and to sustain their source of income. This calls for sustainable management of forests and harmonization of environmental conservation, livelihood needs and socio-economic development aspirations of communities adjacent to forest ecosystems [13]. In addition, FAO [14] noted that in order to reduce poverty especially in rural areas, the contribution made by forests and trees to food security and nutrition deserves urgent consideration. Small holder farmers adjacent to Chyulu hills forest have for long relied on the forest for a number of resources which have had a great impact to their socio-economic life unlike communities far from the forests. Analysis of literature reveals paucity of information on specific forest provisioning ecosystem services extracted from $\mathrm{Ch}$ yulu hills forest by the adjacent communities. The present study therefore examines the types of FPES extracted from Chyulu hills forest by the adjacent households and assesses their relative contribution to local livelihoods and recommends ways to promote community involvement in forest management to enhance forest conservation while still improving livelihoods.

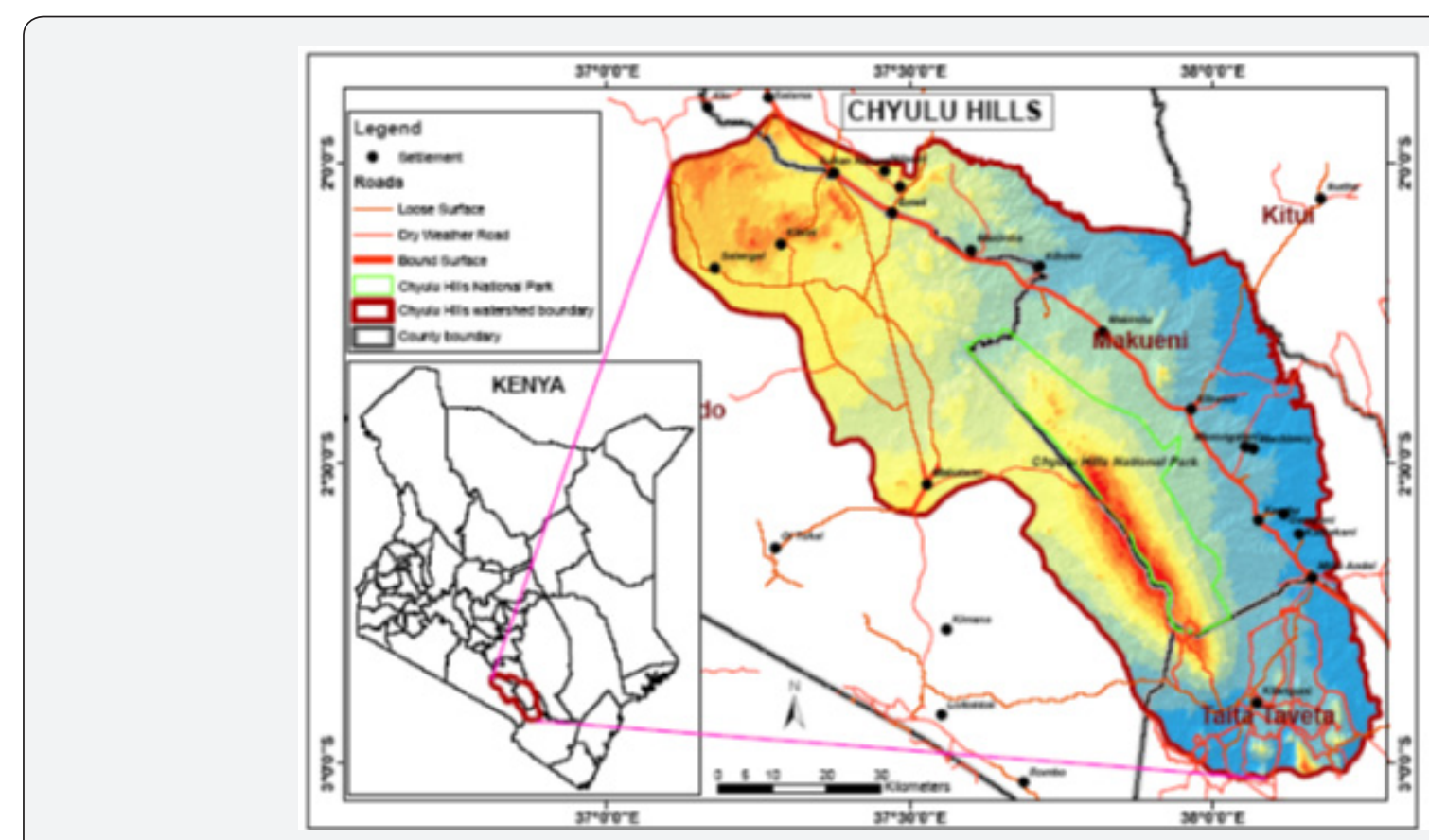

Figure 1: Spatial location of the Chyulu Hills in South Eastern Kenya [19].

\section{Materials and Methods}

\section{Study Area; location and Settlement History}

The study area lies in Makueni County (Figure 1) which covers an area of $8,034.7 \mathrm{Km}^{2}$. The County borders Kajiado to the West, Taita Taveta to the South, Kitui to the East and Machakos to the North. It lies between Latitude 10 35' and 3000 South and Longitude $37^{\circ} 10^{\prime}$ and $38^{\circ} 30^{\prime}$ East. The average land holding in Makueni area is between 2-5 acres per household [15]. Most of the peo- ple live below poverty line, and as a result, they greatly rely on natural resources to improve their livelihood which affects their activities and conservation. The Chyulu hills forest is made up of a series of hills of varying altitude and form a narrow chain of quaternary volcanoes with a Northwest to Southeast elongation covering nearly $100 \mathrm{Km}$ long and up to $30 \mathrm{Km}$ wide [16]. The hills are found between Emali and Mtito Andei townships, along the Nairobi-Mombasa highway. The general landscape in the Chyulu Hills forest is characterized by an arid to semi-arid environment, 
with an annual rainfall of $500 \mathrm{~mm}$ to $1200 \mathrm{~mm}$, and evaporation ranging between $1800 \mathrm{~mm}$ and $2200 \mathrm{~mm}$ [11]. The region, however, has a history of high-density squatter settlements, many of whom still lived in squatter camps in 2008/2009. Absorbing illegal settlers from all the major ethnic groups in Kenya, it has a track record of stark confrontations between land hungry peasants, the Kenya Wildlife Service, civil administration and local politicians [17]. Contestations over land use between squatters and the Kenya Wildlife Service became protracted after gazetting of Chyulu Hills National Park [18]. This was done in two phases, with the lower Chyulu Hills being upgraded to National Park status in 1983 $\left(400 \mathrm{Km}^{2}\right)$, followed by the upper Chyulu Hills extension $\left(380 \mathrm{Km}^{2}\right)$ in 1995. Both were done without adequate consultation with the surrounding community, and without providing for adequate compensation for displaced households. Between 1988 and 1990 many squatters were violently evicted from the Chyulu Hills National Park by the Kenya Wildlife Service and apprehended for illegal occupation and harvesting of sandalwood (Osyris lanceolata), a protected herb [17]. This study was undertaken within approximately $0-12 \mathrm{Km}$ distance from Chyulu forest. It covered two sublocations namely, Mang'elete of Mtito Andei and Kiu of Makindu division, both of Makueni County. The two sub locations were purposively selected as they both border the hills on the part covering the Chyulu hills National Park. Mang'elete is on the fenced border of the Chyulu National park while Kiu sub-location is on the side lacking electric fence between the private lands and the park. Against this background, the study aimed at making comparison on community- park interactions between the two sub-locations. The area mainly comprised of small-scale subsistence agriculture with almost all the natural habitat having been cleared. The area surrounding the park is densely populated and intensively used for farming with almost no permanent grassland or forest. There is widespread dependence on the park by the local people who graze in the forest and also obtain fire wood, thatch grass and medicinal plants among others. There are incidences of illegal logging, charcoal burning and hunting of small animals in the forest in the hill forest [19].

\section{Data collection and analysis}

The study employed a survey design and a three-level sampling procedure. First, the hills adjacent area was stratified based on vicinity to the hills forest. Secondly, two sub-locations directly adjacent to the park were selected (Figure 2) namely, Mang'elete which lie on the fenced border of the forest and Kiu, on the unfenced border. Thirdly, through systematic random sampling, the households, which formed the units of analysis, were selected from within the two sub-locations. This involved identification of two main routes running from the Nairobi-Mombasa highway to the forest, in each sub-location. A transect walk in the farmlands was done selecting the fifth household alternately on either side of the route. On the understanding that the forest adjacent populations in the area are similar in many aspects, the survey drew a sample size of 60 households from the two sub-locations, 30 from each sub-location. The decision over the total number of respondents selected was influenced by the fact that the households are densely placed. It was also guided by World Agroforestry Centre procedural guidelines [20] for characterization of studies at household level. They suggest that a sample size of 40 to 80 households spread over two or three communities which have populations with similar characteristics and attitudes is adequate to make inferences about a larger population. The quantitative data from the survey was sorted, coded and analyzed using the Statistical Package from Social Sciences (SPSS) version 22 and Microsoft Excel 2013. Data were displayed using frequency distribution tables so as to establish various patterns that characterize the phenomena in the study area [21].

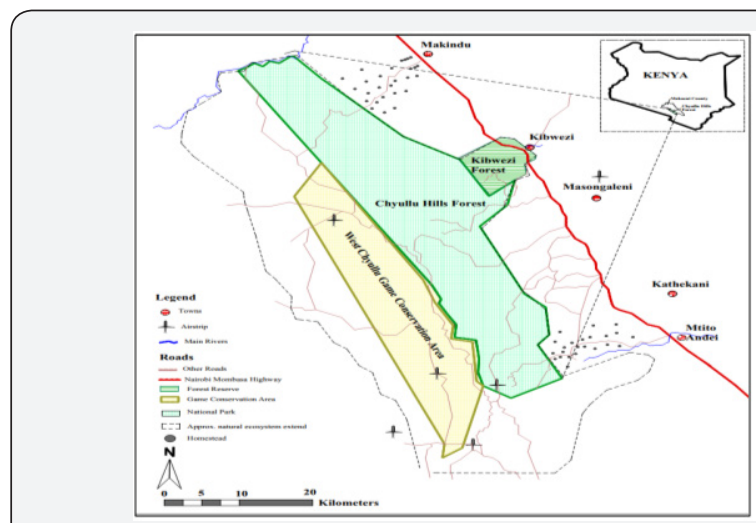

Figure 2: Map of the specific study sites [6].

Results and Discussion Proportions of households extracting forest resources
from Chyulu hills in Kiu and Mang'elete Sub-Locations

Table 1: Proportions of households extracting forest resources.

\begin{tabular}{|c|c|c|c|}
\hline \multirow{2}{*}{ Sub-location } & \multicolumn{2}{|c|}{ Forest resource extraction } & \multirow{2}{*}{} \\
\cline { 2 - 3 } & $\begin{array}{c}\text { Those ex- } \\
\text { tracting (\%) } \\
\text { (n=30) }\end{array}$ & $\begin{array}{c}\text { Those not } \\
\text { extracting (\%) } \\
\text { (n=30) }\end{array}$ & \multirow{2}{*}{ Total \% } \\
\hline Mang'elete & 35.7 & 62.5 & 50 \\
\hline Kiu & 64.3 & 37.5 & 50 \\
\hline Total & 100 & 100 & 100 \\
\hline
\end{tabular}

Results presented in Table 1 indicated that $35.7 \%$ and $64.3 \%$ of the respondents from Mang'elete and Kiu sub-locations respectfully, extracted forestry provisioning ecosystem services from Chyulu Hills Forest. The current trend of results agrees with National Forest Policy Green Paper [22] published in Swaziland, which stated that all rural people directly benefit from the forest as they depend on a range of forest products which are derived from their immediate environment. Studies by Ogutu et al. [23] also indicated that local communities relied on protected forests for grazing, hunting, gathering food, wood and other useful products. Further scrutiny of results showed that those extracting FPES from Kiu were more compared to those from Mang'elete sub-location as evidenced by calculation of a chi-square test of independence comparing the frequency of forest resource extraction in Kiu and Mang'elete sub-locations. A significant interaction was 
found $\left(X^{2}(11)=22.17, p<0.05\right)$, indicating that the extraction was significantly influenced by the sub-location of the respondent. It therefore means that respondents from Kiu benefit more from the forest compared to those in Mang'elete sub-location. This may be attributed to the absence of electric fence in Kiu side of the forest, thereby enabling the residents to have free movements in and out of the forest. In Mang'elete sub-location side, presence of the electric fence and the tight security inhibit people's movements in and out of the forest. The results are in consonance with findings of Mutune et al. [24] who noted that the source of FPES depended on availability as well as ease of access.

\section{FPES extracted from Chyulu hills forest by adjacent communities in Kiu and Mang'elete Sub-Locations, Makueni Country}

Table 2: Forest provisioning ecosystem services (\%) extracted from Chyulu hills forest.

\begin{tabular}{|c|c|c|c|c|}
\hline \multirow{2}{*}{$\begin{array}{l}\text { Forestry Provi- } \\
\text { sioning Ecosys- } \\
\text { tem Services } \\
\text { Extracted from } \\
\text { the Forest }\end{array}$} & \multicolumn{2}{|c|}{ Sub-location } & \multirow{2}{*}{$\begin{array}{c}\text { Chi } \\
\text { Square }\left(X^{2}\right) \\
\text { Value }\end{array}$} & \multirow[b]{2}{*}{ p-Value } \\
\hline & $\begin{array}{l}\text { Mang'elete } \\
(n=30)\end{array}$ & $\begin{array}{c}\text { Kiu } \\
(n=30)\end{array}$ & & \\
\hline Khat & 31.6 & 68.4 & 4.16 & $0.041^{*}$ \\
\hline Firewood & 35.3 & 64.7 & 2.05 & 0.152 \\
\hline Charcoal & 31.2 & 68.8 & 3.07 & 0.08 \\
\hline Medicinal plants & 16.7 & 83.3 & 11.43 & $0.001^{*}$ \\
\hline Poles and posts & 35.7 & 64.3 & 1.49 & 0.222 \\
\hline $\begin{array}{l}\text { Hunting for wild } \\
\text { animals }\end{array}$ & 25 & 75 & 3.75 & 0.053 \\
\hline Fruits gathering & 9.1 & 90.9 & 9.02 & $0.003^{*}$ \\
\hline Timber & 17.6 & 82.4 & 9.93 & $0.002^{*}$ \\
\hline Fodder & 21.4 & 78.6 & 5.96 & $0.015^{*}$ \\
\hline Carving wood & 11.1 & 88.9 & 6.41 & $0.011^{*}$ \\
\hline Honey & 12.5 & 87.5 & 5.19 & $0.023^{*}$ \\
\hline
\end{tabular}

Table 2 presents the different types of forest resources that were extracted from Chyulu hills forest. Analysis of results revealed that out of the total respondents that extracted a particular resource from Chyulu hills, 31.6\% from Mang'elete sub-location extracted khat, 35.3\% firewood, 31.2\% charcoal, $16.7 \%$ medicinal plants, $35.7 \%$ poles and posts, $25.0 \%$ wild animals, $9.1 \%$ fruits, $17.6 \%$ timber, $21.4 \%$ fodder, $11.1 \%$ wood for curving and $12.5 \%$ honey. From Kiu sub-location, $68.4 \%$ extracted khat, $64.7 \%$ firewood, $68.8 \%$ charcoal, $83.3 \%$ medicinal plants, $64.3 \%$ poles and posts, $90.9 \%$ fruits, $82.4 \%$ timber, $78.6 \%$ fodder, $88.9 \%$ wood for curving and $87.5 \%$ honey. In addition, $75.0 \%$ hunted wild animals from the forest.

Types of forestry provisioning ecosystem services harvested from the Chyulu hills by the two Sub-locations are firewood, charcoal, carving wood, fodder, honey, poles and posts, khat, timber, fruits, medicinal plants and game meat from the forest. This is in conformity with FAO [25] report which sated that wood products from tropical countries are used as fuel (between 40 and $80 \%$ ), and about $80 \%$ of the collected wood in Africa is used for fuel wood and for charcoal making. It is evident from the data that most of the respondents who extracted a particular resource from Chyulu hills were from Kiu sub-location. Results of chi square test of independence comparing the frequency of FPES extraction and sub-location of the respondent (Table 2) indicated that extraction of several FPES was significantly influenced by the sub-location of the respondent. This included khat $\mathrm{X}^{2}(1)=4.16$, $\mathrm{p}$-value=0.04), medicinal plants $\left(\mathrm{X}^{2}(1)=11.43\right.$, $\mathrm{p}$-value $\left.=0.00\right)$, fruits gathering $\left(X^{2}(1)=9.02, p\right.$-value $\left.=0.00\right)$, timber $\left(X^{2}(1)=9.93, p\right.$-value=0.00 $)$, fodder $\left(X^{2}(1)=5.96, p\right.$-value $\left.=0.01\right)$, carving wood $\left(X^{2}(1)=6.41\right.$, $p$-value $=0.01)$, and honey $\left(X^{2}(1)=5.19, p\right.$-value $\left.=0.02\right)$. The findings were attributed to the fact that the sub-locations did not have similar characteristics which influenced extraction of a resource such as easiness to access of the forest. More and different types of FPES were extracted by communities living in Kiu sub-location side of the forest compared to Mang'elete side of the forest. In Mang'elete sub-location, a number of the residents view the forest as their only source of livelihood and therefore not even the electric fence can deter them. They dig under it and sometime cut wires to gain access to the forest or are forced to wait for power to go off to enter the forest. These results agree with findings of similar studies in Eastern Kenya, Southern Rift and Mt. Kenya which revealed that local utilization of local forest resources by the forest adjacent communities is imperative and any action to deny the households from forest utilization limits their livelihood opportunities [26].

\section{Food resources extracted from Chyulu hills forest by adjacent communities in Kiu and Mang'elete Sub- Locations, Makueni Country}

Table 3: Food resources (\%) extracted from Chyulu hills forest by adjacent communities in Kiu and Mang'elete Sub-Locations

\begin{tabular}{|c|c|c|c|c|}
\hline \multirow{2}{*}{$\begin{array}{l}\text { Food Materials } \\
\text { Extracted from } \\
\text { the Forest }\end{array}$} & \multicolumn{2}{|c|}{ Sub-location } & \multirow{2}{*}{$\begin{array}{c}\text { Chi } \\
\text { Square }\left(X^{2}\right) \\
\text { Value }\end{array}$} & \multirow[b]{2}{*}{ p-value } \\
\hline & $\begin{array}{c}\text { Mang'elete } \\
(\mathrm{n}=\mathbf{3 0})\end{array}$ & Kiu $(n=30)$ & & \\
\hline Wild fruits & 30.8 & 69.2 & $6.79(1)$ & $0.01^{*}$ \\
\hline Vegetables & 44.4 & 55.6 & $0.32(1)$ & 0.57 \\
\hline Game meat & 34.6 & 65.4 & $4.34(1)$ & $0.04^{*}$ \\
\hline Honey & 12.5 & 87.5 & $5.19(1)$ & $0.02^{*}$ \\
\hline
\end{tabular}

Food resources extracted from Chyulu Hills Forest were categorized into wild fruits, vegetables, game meat and honey (Table 3). Results indicated that in Mang'elete sub-location, 30.8\% of the respondents extracted wild fruits, $44.4 \%$ vegetables, $34.6 \%$ game meat and $12.5 \%$ honey. Similarly, in Kiu sub-location, $69.2 \%$ of the respondents extracted wild fruits, $55.6 \%$ vegetables, $65.4 \%$ game meat and $87.5 \%$ honey.

Results of chi square test of independence (Table 3 ) indicated that extraction of wild fruits $\left(X^{2}(1)=6.79, p\right.$-value $\left.=0.01\right)$, game meat $\left(X^{2}(1)=4.34, p\right.$-value $\left.=0.04\right)$ and honey $\left(X^{2}(1)=5.19\right.$, $p$-value $=0.02$ ) was significantly influenced by the sub-location of the respondent. More food materials were extracted in Kiu sub-loca- 
tion compared to Mang'elete sub-location. In Mang'elete sub-location, the most extracted food material was vegetables with $44.4 \%$ and the least extracted was honey with $12.5 \%$. In Kiu sub-location the most extracted was honey with $87.5 \%$ while the least extracted was vegetables at $55.6 \%$. The percentage of food extraction in Kiu sub-location was higher compared to Mang'elete.

\section{Medicinal plants extracted from Chyulu hills forest by adjacent communities in Kiu and Mang'elete Sub}

\section{locations}

Table 4: Medicinal resources (\%) extracted from Chyulu hills forest by adjacent communities in Kiu and Mang'elete Sub-Locations.

\begin{tabular}{|c|c|c|c|c|}
\hline \multirow{2}{*}{$\begin{array}{l}\text { Medicinal Plants } \\
\text { Extracted from } \\
\text { the Forest }\end{array}$} & \multicolumn{2}{|c|}{ Sub-location } & \multirow{2}{*}{$\begin{array}{c}\text { Chi } \\
\text { Square }\left(X^{2}\right) \\
\text { Value }\end{array}$} & \multirow{2}{*}{ p-value } \\
\hline & $\begin{array}{l}\text { Mang'elete } \\
(n=30)\end{array}$ & $\begin{array}{c}\text { Kiu } \\
(n=30)\end{array}$ & & \\
\hline Aloe vera (Kiluma) & 45 & 55 & $0.30(1)$ & 0.58 \\
\hline $\begin{array}{l}\text { Azadirachta indica } \\
\text { (Neem tree) }\end{array}$ & 47 & 52 & $0.08(1)$ & 0.78 \\
\hline $\begin{array}{l}\text { Grewia bicolor } \\
\quad \text { (Kilawa) }\end{array}$ & 39.1 & 60.9 & $1.76(1)$ & 0.18 \\
\hline $\begin{array}{l}\text { Solanum incanum } \\
\text { (Mutongu) }\end{array}$ & 50 & 50 & $0.00(1)$ & 1 \\
\hline $\begin{array}{l}\text { Terminalia brownii } \\
\text { (Muuku) }\end{array}$ & 52.4 & 47.6 & $0.07(1)$ & 0.79 \\
\hline $\begin{array}{l}\text { Albizia anthel- } \\
\text { mintica (Kyoa) }\end{array}$ & 40 & 60 & $1.71(1)$ & 0.19 \\
\hline $\begin{array}{l}\text { Acacia nilotica } \\
\quad \text { (Kisemei) }\end{array}$ & 40 & 60 & $1.71(1)$ & 0.19 \\
\hline
\end{tabular}

Findings presented in Table 4 shows proportions of respondents who extracted medicinal resources from Chyulu hills. In Mang'elete sub location, $45.0 \%$ extracted Aloe vera, 47\% Azadirachta indica, 39.1\% Grewia bicolor, 50\% Solanum incanum, 52.4\% Terminalia brownii, 40\% Albizia anthelmintica and 40\% Acacia nilotica. This is compared with Kiu sub location, where 55\% extracted Aloe vera, 52.0\% Azadirachta indica, 60.9\% Grewia bicolor, 50\% Solanum incanum, 47.6\% Terminalia brownii, $60.0 \%$ Albizia anthelmintica and $60 \%$ Acacia nilotica. A chi square test of independence values comparing the frequency of medicinal plants extraction in both sites (Table 4) shows that all medicinal plants extraction $(p>0.05)$ was not influenced by the sub-location of the respondent. However, the extraction of medicinal plants was generally higher in Kiu compared to Mang'elete sub-location.

Medicinal plants extracted were purely for subsistence use. This could be attributed to the fact that in the nearest market centres there are quality health services and therefore few people depended on herbal medicine. In Mang'elete the most extracted herbal was Terminalia brownii with $52.4 \%$ while in Kiu sub location the most extracted was Grewia bicolor with $60.9 \%$.

\section{Conclusion and Recommendations}

The findings showed that the Chyulu forest is very important for provision of various FPES. From the study, the categories of FPES that are extracted from Chyulu hills forest by the households include food materials, wood fuel, medicinal plants, khat, build- ing materials, animal fodder and carving wood. The food materials extracted are fruits, honey, vegetables and bush meat. Wood fuel include firewood and charcoal burning. Medicinal plants extracted are Aloe vera, Azadirachta indica, Grewia bicolor, Solanum incanum, Terminalia brownii, Albizia anthelmintica and Acacia nilotica. The study concluded that access to forest in Mang'elete sub-location was hindered by presence of electric fence. In Kiu sub-location; access to the forest is easier as there is no electric fence. Further, it can be concluded that communities near the forest generally rely on FPES to support their livelihoods. The rural people in the study area are greatly dependent on the forest for their livelihood with little or no alternative livelihood sources. Their main livelihood activities comprise of farming, collection of fuel wood, hunting and charcoal burning. In view of the foregoing, the communities living adjacent to the forests should be actively involved in the conservation activities so that they can secure their livelihoods.

\section{Acknowledgement}

The authors are grateful to household heads for willingly and freely offering information during the study that led to the preparation of this paper.

\section{References}

1. Shackleton C, Shackleton S (2004) The importance of non-timber forest products in rural livelihood security and as safety nets: A review of evidence from South Africa. South African Journal of Science $100(11-12): 658-664$.

2. Maass JM, Balvanera P, Castillo A, Daily GC, Mooney HA, et al. (2005) Ecosystem services of tropical dry forests: Insights from long-term ecological and social research on the Pacific Coast of Mexico. Ecology and Society 10(1): 1-17.

3. FAO (2010) Policy on Indigenous and Tribal Peoples. Rome, pp. 1-44.

4. International Union for Nature Conservation (IUCN) (2001) The Economic Value of East Africa's Forests.

5. Balmford A, Bruner A, Cooper P, Constanza R, Farber S, et al. (2002) Economic Reasons for Conserving Wild Nature. Science 297(5583): 950-953.

6. (2014) ROK (Republic of Kenya) Forestry policy.

7. Calibre Consultants (2000) Number of forest dependent people; A feasibility study.

8. Shackleton S, Campbell B, Wollenberg E, Edmunds D (2002) Devolution and Community Based Natural Resource Management: Creating Space for Local Peopl to Participate and Benefits. Overseas Development Institute, Briefing Paper 76: 1-6.

9. Neumann RP, Hirsch E (2000) Commercialisation of non-timber forest products: Review and analysis of research. Bogor, Indonesia: Center for International Forestry Research; Rome: FAO, pp. 1-187.

10. Land use in Kenya (2006) The case for a national land-use policy. Kenya land alliance, Land reform. (2002;3). In: Anderson J, et al. (Eds.), Forests, poverty and equity in Africa: New perspectives on policy and practice. International Forestry Review 8: 1.

11. Muriuki G, Leonie S, Clive M, Chris J, Bronwyn P, et al. (2011) Landcover change under unplanned human settlements: a study of the Chyulu Hills squatters, Kenya. Landscape and Urban Planning 99(2): 154-165. 
12. Timko JA, Waeber PO, Kozak RA (2010) The socio-economic contribution of non-timber forest products to rural livelihoods in SubSaharan Africa: Knowledge gaps and new directions. International Forestry Review 12(3): 284-294.

13. United Nations (UN) (2007) The Millennium Development Goals Report 2007.

14. FAO (2007) Forests and the forestry sector -Zambia.

15. Kenya National Bureau of Statistics (2010) The 2009 Kenya Population and Housing Census: Counting our People for the Implementation of Vision 2030|| vol 1A, Nairobi, Kenya.

16. Spath A, le Roex AP, Opiyo-Akech N (2000) The petrology of the Chyulu Hills volcanic province, Southern Kenya. Journal of Africa Earth Sciences 31(2): 337-358.

17. Freeman E, Lawrence M, Christofferman C, Kiilu JM (2004) The impacts of migration on establishment of social capital and environmental degradation in Kibwezi, Kenya. In: Garcia-Frapolli EG, Ramos Fernande, E (Eds.), Third World Conference Foundation, Chicago.

18. Okello MM, Tome S (2007) The Chyulu Hills: Raison d'Etre and consequences of contested proprietorship of an idyllic resource oasis. In: Wishitemi, B, Spenceley A, Wels H (Eds.), Culture and Community: Tourism studies in Eastern and Southern Africa. Rozenberg Publishers, Amsterdam, pp. 123-137.

19. Kiringe JW, Mwaura F, Wandera P, Kimeu M, Gachuga F (2015) Water management tools in the Chyulu Hills Watershed. Report prepared for the African Wildlife Foundation (AWF) by Habitat Planners, Nairobi, Kenya.

20. Nyariki DM, Kitalyi A, Wasonga VO, Isae I, Kyagaba E, et al. (2005) Indigenous Techniques for Assessing and Monitoring Range Resources in East Africa. Occasional Paper No. 2. Nairobi, World Agroforestry Centre, Kenya.

21. Mugenda OM, Mugenda AG (2003) Research Methods. Quantitative and Qualitative Approaches. African Press for Technology Studies Press, Nairobi.

22. National Forest Policy Green Paper (2000) Environmental Consulting Services, Mbabane.

23. Ogutu ZA, Kamngisha JR, Statu M (1997) Parks and PeopleConservation \& Livelihood at the Crossroads. English Press, Nairobi.

24. Mutune JM, Wahome RG, Mungai DN (2015) Local Participation in Community Forest Associations: A Case Study of Sururu and Eburu Forests, Kenya. International Journal Africa Asian Stud 13: 1-13.

25. FAO (2009) Food and Agriculture Organization of the United Nations. Crop evapotranspiration: Guidelines for computing crop water requirements - FAO Irrigation and drainage paper 56, Rome, Italy.

26. Emerton L (2001) Valuing the Environment: Case Studies from Kenya. Africa Wildlife Foundation, Nairobi, p. 43.

\section{Your next submission with Juniper Publishers} will reach you the below assets

- Quality Editorial service

- Swift Peer Review

- Reprints availability

- E-prints Service

- Manuscript Podcast for convenient understanding

- Global attainment for your research

- Manuscript accessibility in different formats

( Pdf, E-pub, Full Text, Audio)

- Unceasing customer service

Track the below URL for one-step submission https://juniperpublishers.com/online-submission.php 